\title{
Response to'Effect of etanercept in polymyalgia rheumatica: a randomized controlled trial'
}

\author{
Pippa Watson* and Hill Gaston \\ See related research by Kreiner and Galbo, http://arthritis-research.com/content/12/5/R176
}

We read with interest the article recently published in Arthritis Research \& Therapy by Kreiner and Galbo [1] that reported a very modest benefit of etanercept monotherapy in polymyalgia rheumatica (PMR). There is some evidence that TNF $\alpha$ can be found in the lesions of giant cell arteritis (GCA) [2]. However, two previous randomised controlled trials $[3,4]$ showed no benefit of TNF $\alpha$ inhibition in the treatment of PMR/GCA. We report for the first time the development of PMR and GCA in two patients undergoing treatment with antiTNF $\alpha$ drugs. This suggests that the underlying immunopathology of GCA/PMR is not driven by TNF $\alpha$ and casts further doubt on the likely usefulness of TNF $\alpha$ blockade in these conditions.

The first patient was a woman aged 72 years with ankylosing spondylitis. Adalimumab was commenced in July 2006 with good effect. On review in August 2009 she reported increasing pain and stiffness in her shoulders and pelvic girdle. Her 'usual' ankylosing spondylitisrelated lower back pain remained well controlled. Her new symptoms did not respond to diclofenac; however, within 48 hours of starting prednisolone $15 \mathrm{mg}$ once daily there was a marked and sustained improvement. This was maintained until in subsequent months prednisolone was reduced to $5 \mathrm{mg}$, when recurrence of symptoms again responded promptly to an increased dose. The rapid response to glucocorticoids and the sensitivity to changes in dose strongly support the clinical diagnosis of PMR.

The second patient, a woman aged 75 years, was treated with adalimumab $40 \mathrm{mg}$ fortnightly, and daily leflunomide $10 \mathrm{mg}$ and prednisolone $7.5 \mathrm{mg}$ for seropositive erosive rheumatoid arthritis. Initially, she responded well to adalimumab but 8 months later significantly elevated erythrocyte sedimentation rate $(84 \mathrm{~mm} / \mathrm{h})$ and C-reactive protien $(87 \mathrm{mg} / \mathrm{L})$ were noted on monitoring. On review there was no worsening of joint pain, and she did not

*Correspondence: pippawatson@doctors.org.uk

Addenbrookes Hospital, Hills Road, Cambridge, CB2 0QQ, UK volunteer other symptoms. However, direct questioning revealed a worsening headache, jaw ache on chewing, and visual disturbance. A clinical diagnosis of GCA was made and her glucocorticoid dose increased to $60 \mathrm{mg}$ daily, resulting in a rapid improvement in her symptoms. Temporal artery biopsy revealed changes typical of GCA.

Our two cases, who developed GCA and PMR, respectively, whilst on anti-TNF $\alpha$ therapy, support the opinion expressed by Luqmani [5] that use of anti-TNF $\alpha$ in the treatment of these conditions is unlikely to be successful. Efforts should instead be focused on other potential cytokine targets, such as interleukin-6, and on optimal use of glucocorticoids and appropriate measures to minimise their inevitable side effects.

Abbreviations

GCA, giant cell arteritis; PMR, polymyalgia rheumatica; TNF, tumour necrosis factor.

\section{Competing interests}

The authors declare that they have no competing interests.

Published: 6 April 2011

\section{References}

1. Kreiner F, Galbo H: Effect of etanercept in polymyalgia rheumatica: a randomized controlled trial. Arthritis Res Ther 2010, 12:R176.

2. Field M, Cook A, Gallacher G: Immuno-localisation of tumour necrosis factor and its receptors in temporal arteritis. Rheumatol Int 1997, 17:113-118.

3. Hoffman GS, Cid MC, Rendt-Zagar KE, Merkel PA, Weyand CM, Stone JH, Salvarani C, Xu W, Visvanathan S, Rahman MU; Infliximab-GCA Study Group: Infliximab for maintenance of glucocorticosteroid-induced remission of giant cell arteritis. A randomized trial. Ann Intern Med 2007, 9:621-630.

4. Salvarani C, Macchioni P, Manzini C, Paolazzi G, Trotta A, Manganelli P, Cimmino M, Gerli R, Catanoso MG, Boiardi L, Cantini F, Klersy C, Hunder GG: Infliximab plus prednisone or placebo plus prednisone for the initial treatment of polymyalgia rheumatica. A randomized trial. Ann Intern Med 2007, 9:631-639.

5. Luqmani R: Treatment of polymyalgia rheumatica and giant cell arteritis: are we any further forward? Ann Intern Med 2007, 146:674-676. 